\title{
Customer's Adoption for Technology-Enabled Delivery Channels in Selected Public Sector Banks
}

\author{
Neha Gupta ${ }^{1} \&$ Vandana Tandon Khanna ${ }^{1}$ \\ ${ }^{1}$ Marketing Department, K. J. Somaiya Institute of Management Studies \& Research, India \\ Correspondence: Neha Gupta, Marketing Department, K. J. Somaiya Institute of Management Studies \& \\ Research, India. E-mail: neha_prasad2005@yahoo.com
}

Received: August 10, 2015

Accepted: September 21, $2015 \quad$ Online Published: November 25, 2015

doi:10.5539/ijbm.v10n12p215

URL: http://dx.doi.org/10.5539/ijbm.v10n12p215

\begin{abstract}
Purpose-The purpose of this paper is to investigate customer's adoption for technology-enabled delivery channels such as Automated Teller Machines (ATMs), Internet banking, Tele-banking, mobile banking and branch lobby kiosks of selected Public Sector Banks (PSBs). In addition, the study consists of the customer's willingness for adopting banks delivery channels and customer demographics influence on delivery channels in specific for Mumbai city (India).

Design/methodology/approach-For this study, structured questionnaire was administered to collect the primary data and random sampling method was adopted. The paper also presents a multi-year research effort on e-banking in delivery channels and suggests strategies to enhance the channelization of banking products and services through usage of delivery channels.

Findings-The findings reveal that the customer's willingness for adoption of various technology-enabled delivery channels is lower than the banks' acceptable level. The usage of technology-enabled delivery channels such as Automated Teller Machines (ATMs) and Internet banking is high in Mumbai. The results also show that the usage of mobile banking and branch lobby kiosks is very low. Most of respondents are using Internet banking for the purpose of fund transfer and account information. ATMs service is highly used among 36-45 years of age groups. Promoting awareness about benefit of technology-enabled delivery channels is of utmost important to increase usage of technology-enabled delivery channels.
\end{abstract}

Practical implications/limitations-The paper presents the opportunity for bank marketers to adapt to market orientated approach. They can consider customers usage pattern to increase the effectiveness of delivery channels. The results suggest that banks strategic and tactical activities require improvement in order to become more customer-focused and market-oriented. Furthermore, the scope of the study was selected PSBs' customers residing in Mumbai city (India).

Originality/value-Previous studies that sought adoption of innovative delivery channels lack concern to user's inclination to technology-enabled delivery channels. This paper makes a valuable contribution in the field of marketing strategy of banks, and evaluate to what extent consumers are ready to accept and use the products or the services introduced.

Keywords: ebanking, delivery channels usage, customer satisfaction, service quality and customer retention

\section{Introduction}

The bank markets have faced a rapidly changing environment and become increasingly competitive following liberalization and deregulation. As a result, information technology has become one of the most powerful strategic tools for banks to ensure profitability and to develop their market position. Technology advancement and digitization influence social networking by providing the gateway to innovate \& experiment for networking; it has evolved into one-to-one sales and marketing platform for banks. Bank Services because of its nature and characteristics face challenge to evaluate service quality and customer convenience.

Customer satisfaction is the key for any business as it leads to profitability and ultimately it is for customers' retention. Today, banks are connecting the customers through enhanced services with quality as major parameter. Such revolutionized change and dynamic market environment raises the question about the customers' satisfaction or dissatisfaction and also the related elements of retail banking becoming reason for customers' 
satisfaction and dissatisfaction.

Although PSBs banks have made a beginning, they need to look beyond the mere capabilities of eBanking and use the analytical tools such as web mining in the background to understand the customer better. This allows them to offer more personalized products and relevant services to the customer in an integrated manner.

In this contemporary era, banking services are being render to the customers by exploring, exploiting and harnessing information technology to the fullest. Information Technology (IT) has played a very crucial role in delivery of banking services to various segments of the society. IT has helped banks to deliver their products and services in the drawing hall of the customers anytime, anywhere by overcoming the limitations on geographical/physical reach in branch banking. It also eases the resource and volume constraints posed by the brick and mortar model. For the banks, the question is no longer limited to whether mobile banking will be an important part of their business or not. Nevertheless, how best they can manage a rapidly evolving channel to deliver better customer service, expand product range, retain market-share, and enhance revenue. This helps them to drastically reduce operating expenses and remain socially relevant without sacrificing sustainability in technology-enabled financial inclusion plans. The following graphical representation explains the adoption of technology and its impact by giving new definition to the way service deliver.

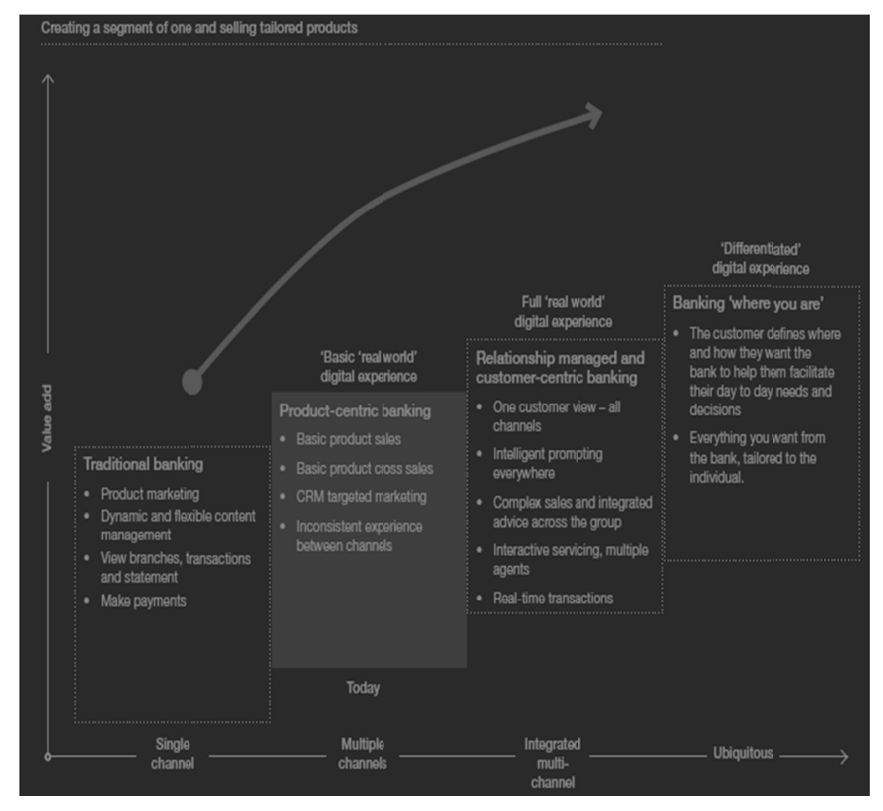

Figure 1. The adoption of technology and its impact by giving new definition to the way service deliver

Source: CII Banking TECH Summit report/ 2012 edition /Mumbai, 28 June 2012.

Changing needs of the customers and newer regulation have changed the banks functioning. Large section is traditional customers; require personalized approach to banking products and services. However, new generation customers prefer agility and convenience.

Price water Cooper's (PwC's) survey (2013) aims to highlight the key innovation made across the changing paradigms of services, products and experiences for banking customers. A large percentage of respondents feel that managing customer experience and the emergence of new technologies and products will be the key drivers for innovation.

Alternative banking is an option for availing banking services other than traditional means. According to Howcroft (1993), alternative distribution channels provide convenient alternatives to branch banking. Kumbhar (2009) suggested that in the traditional banking system, customers need to visit branch to make transaction and for getting information about banking services, account information etc.; but in the alternative banking there is no need to visit physical branch, most of banking transactions are possible through alternative channels.

Banks therefore, are undertaking channel migration initiatives to increase enrolment of new customers and increase usage across customers who have already enrolled for the Internet banking service. In order to increase 
enrolment and activation, banks are now integrating the opening of an online account along with the basic account opening process so that a new customer receives their online banking credentials along with the welcome kit. After the customer has enrolled, there is a need to create an ecosystem that drives the channel usage for enrolled customers.

The significance of the study is to cover business, application, information and technology, usage of technology-enabled delivery channels with customer's perception / readiness to have a better understanding of the problem domain. This study will help the Public Sector Banks to understand the importance of enhancing the effective usage of technology-enabled delivery channels for marketing their products and services as well as gaining customer satisfaction.

\section{Literature Review}

Customer service is a key element in customer retention. Most of the banks whether public sectors, private sectors or foreign banks are using eBanking as a key strategy to sell their products and services at the same time due to stiff competition and increasing demand banks are now revolutionizing their strategy to cope with competition and balancing it with service quality.

Private sector banks came up with anytime anywhere banking where customers can download banks mobile application to freely access account information, performing transaction and even transferring fund. Some of the largest public sector banks are focusing on eBanking to flourish their retail business by way of introducing the sale of retails products through online medium of their own website, mobile App and so on. Parasuraman et al. (1985) suggested that the quality of services delivered to the customer is the key strategy for any business institution. The customer satisfaction and attitudinal loyalty are determined by the quality of service offered by the institution.

Banking services has re-designed with the use of Information Technology and processes. In future, banking will offer more services that are sophisticated to the customers with the continuous product and process innovations. This will induce the paradigm shift from the seller's market to buyer's market in the industry. Influencing the bankers approaches to customers by modify the banking service and delivery mechanism from "traditional banking to eBanking" i.e. shifting from "mass banking to class banking". The move has also increased the degree of accessibility of a common person to bank for his variety of needs and requirements.

Ram and Sheth (1989) presented a theoretical framework for consumer resistance to innovations. They suggested two core resistance constructs-functional and psychological. They categorized functional into three constructs namely usage barrier, value barrier, and risk barrier, and two constructs namely tradition barrier and image barrier for the psychological barriers. This framework had been applied in some of the earlier studies regarding banking technologies (Fain \& Roberts, 1997; Laukkanen et al., 2007, 2008, 2009; Cruz et al., 2009). Zineldin, M. (2000) studied the use of technology in relationship marketing by considering relationship marketing, based on technological advances as a new paradigm and found that without effective use of technology, relationship marketing would not be an effective strategy. Lang and Colgate (2003) investigated the impact of IT in a relationship-marketing context to understand how customers use a combination of IT channels to interact with their financial service provider and how this interaction affects the relationship quality between the customer and the financial service provider.

Davis (1989) developed and validated new scales for two specific variables, perceived usefulness and perceived ease of use, which are hypothesized to be fundamental determinants of user acceptance. He found that perceived usefulness had a significant correlation with usage behavior than ease of use. They conducted regression analyses and suggested that the perceived ease of use might actually be a causal antecedent to perceived usefulness, as opposed to a parallel, direct determinant of system usage. Joseph (1996) explored the use of Internet by companies to improve the marketing of their commercial businesses. Author focused on the practical aspect of the mapping and customizing of firm's resources to the needs of their customers and suggested that tools of the Internet can be used to add value to their products.

Grönroos (2000) studied the dimensions of the service quality and identified them as functional and technical quality of the service. Author related these dimensions of the service quality as how the service performance and what of the customer's service experience. This conceptualization is also known as the Nordic model of perceived service quality as shown in (Figure 2). The Nordic Model states that the customers' perception about the way the service delivered holds more importance than any other aspect. However, it is relatively difficult to define the technical quality or result of some services through the Nordic Model Kang and James (2004). In defining service quality, Grönross (1982) also took into account the company image. Author related the customers' awareness of their previous experiences with the company and their overall perceptions of its service; 
this, in turn, influences their perceptions of current service quality.

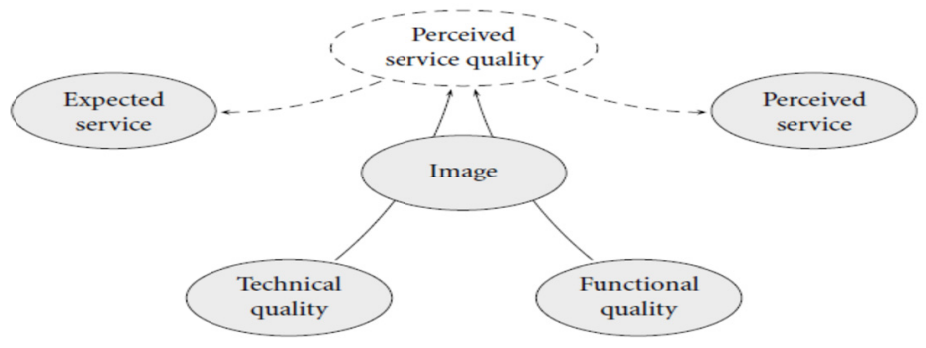

Figure 2. Nordic model

Source: Nordic model of perceived service quality (adapted from Grönroos 1984).

Mariappan (2005) described about the changing way of banking and stated that the IT revolution has brought stunning changes in the business environment as such no other sector been influenced by advances in technology as much as banking and finances.

Gerrard et al. (2006) conducted study in Singapore; they identified the factors why certain consumers of Singapore were resistant to using internet banking. Using a content analysis procedure, they identified eight factors for not using Internet banking. The two most frequently mentioned factors were perceptions about the risks associated with Internet banking and the lack of perceived need. In the order of frequency, the factors were perceptions about risk; the need; lacking knowledge; inertia; inaccessibility; human touch; pricing and IT fatigue.

Xue et al. (2007) used prior theoretical frameworks in service operations and economics to hypothesize relationships among customer characteristics (especially coproduction efficiency), channel utilization, and firm performance and tested these hypotheses using panel data from a large retail bank. They suggested that higher customer efficiency in self-service channels was associated with greater profitability and had a complex relationship with customer retention and product utilization.

Dharmarajan and Srinivasan (2007) stated that Indian banking today is witnessing drastic changes. Technology has a definitive role in facilitating transactions in the banking sector and the impact of technology implementation has resulted in the introduction of new products and services by various banks in India. As foreign and private banks poured huge sums of money to counter the branch advantage of public sector banks, they discovered that technology gives them a large competitive advantage. The achievements in the banking today would not have been possible without IT revolution. Alam et al. (2009) summarizes academic literature on Internet banking drivers and found that there is a need to conduct research on customer Internet banking adoption in Malaysia. They examined the relationship between Internet banking adoption and its six factors, namely awareness, ease of use, security, cost, reluctance to change and accessibility. They found that four factors were significantly important to the adoption of Internet banking, however, perceive ease of use and reluctant to change were found to be insignificant in determining its adoption.

Uppal (2010) concluded that there is a paradigm shift in the performance of all bank groups in the post e-banking period, new private sector banks and foreign banks have an edge over Public Sector Banks (PSBs). He has stressed on customer-centric, proficiency in managing assets, technology, skilled staff, transparency, human resource management policies, customer relationship management, and merger and acquisition policies as vital factors to enhance the performance of banks to face the emerging global competition.

Deloitte, in its report 'Digital Disruption: Short Fuse, Big Bang?' (2012) analyzed the potential impact of a new wave of technology disruption on traditional industries and concluded: "Sectors such as financial services, IT (Information Technology) and media have some of the highest level of total digital potential. It also suggested that even though these sectors have already changed considerably due to digital technologies, there is plenty more disruption ahead". Martin (2012) studied the digital disruption and suggested that the disruption driven by the rapid change in technology and fueled by customer desire is faster, better and stronger. Author noted that such disruption will lead a fundamental transition and upheaval of products in nearly every industry.

Kundu and Datta (2012) did a comparative evaluation on some identified parameters of iBanking and mBanking of three selected Indian PSBs from four major metro cities of India. They found that for services like e-shopping, 
electronic fund transfer, utility bill payments, tax payments, and balance enquiry iBanking was more suitable as a channel of delivery. For those having experience of mBanking had shown a clear inclination toward mBanking for value-added services like movie ticket booking. The factors identified from the perceptional analysis of iBanking indicated that people like to use iBanking mainly for reducing the lead-time of operation and transaction intensive services. They suggested that iBanking and mBanking could be regarded as services complementary to each other.

Cheng et al. (2014) identified and analyzed the relationship between user resistance and different factors from innovation and user's characteristics. They found that the social influence and perceived complexity had positive effect on perceived risk, and trust had negative effect on perceived risk, perceived security and perceived protection of private information was having no effect on perceived risk. Perceived risk had positive effect on user resistance.

\section{Research Methodology}

The study was based on the primary data collected through the structured questionnaire to have a thorough understanding about customer's usage pattern for technology-enabled delivery channels of selected Public Sector Banks (PSBs) in Mumbai.

The random sampling method was adopted for selection of sample. Fifteen Public Sector Banks (PSBs) were randomly selected such as State Bank of India (SBI), Union Bank of India (UBI), Canara Bank (CB), Bank of Baroda (BOB) and so on. A total number of 435 responses were received against 450 questionnaire sent to the selected PSBs' customers. The total number of questionnaire found suitable for data analysis was 376 .

\subsection{Setting of Hypothesis}

We set the following hypotheses separately for each technology-enabled delivery channels. To analyze the customer's usage pattern of technology-enabled delivery channels based on age groups and annual income.

$\mathrm{H}_{0}$ : There is no significant difference in the usage pattern of the technology-enabled delivery channels with respect to age groups and annual income.

$\mathrm{H}_{1}$ : There is a significant difference in the usage pattern of the technology-enabled delivery channels with respect to age groups and annual income.

\subsection{Statistical Tool for Analysis}

Analysis of variance (ANOVA) was constructed for determining whether three or more sample means were drawn from population with equal means or unequal means. The F-test value indicates that there is a significant difference in the mean performance of responses given for concerned samples. The significance level $(0.05)$ is taken into consideration for comparing the calculated value with the tabulated values.

\section{Data Analysis and Finding}

\subsection{Reliability and Validity of Data}

To check the reliability of the questionnaire items, reliability analysis was conducted for the scales and the applicable questionnaire. The Cronbach's alpha is 0.803 and the Bartlett's test of sphericity was found significant as value was $0.000(\mathrm{p}<0.001)$. The questionnaire is reliable.

\subsection{Frequency Distribution and Cross-Tab Analysis for Respondents}

Cross-tab analysis and frequency distribution has been performed for basic demographics such as age groups, qualification, current profession \& annual income and innovative delivery channels usage. The outcome of the analysis is as under: 


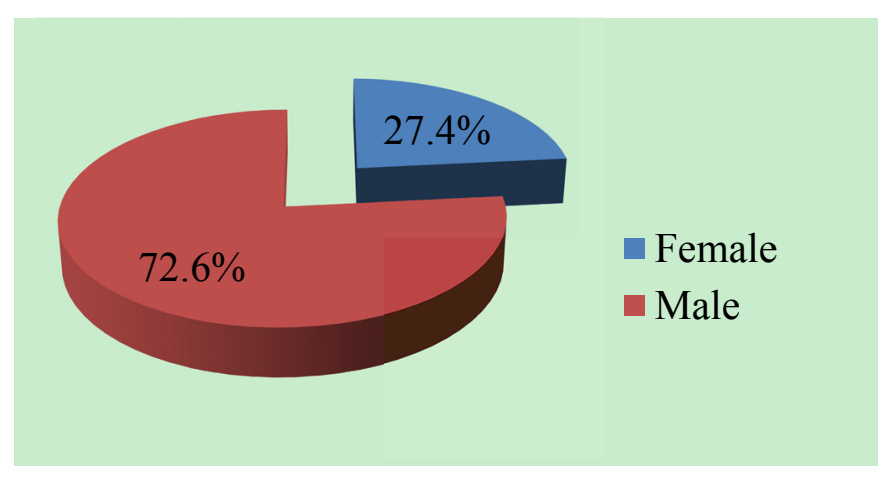

Figure 3. Respondents classification based on gender

\subsubsection{Demographics Details}

It has been found that Out of 376 respondents, $72.6 \%$ respondents are male. $38.8 \%$, respondents are in the age group of $26-35$ years. $31.9 \%$ respondents are professionals. $35.4 \%$ respondents are self-employed and $51.1 \%$ respondents are salaried. $39.9 \%$ of respondents are in the annual income range from two lakhs to five lakhs.

\subsubsection{Usage of Delivery Channels}

The findings show that $94.2 \%$ respondents are retail-banking customers. 96.5\% respondents are using ATMs. $75.3 \%$ respondents are using Internet Banking. The results also show that $42.3 \%$ respondents are using Mobile banking. $27.4 \%$ respondents are using Tele banking and only $24.2 \%$ respondents are using branch lobby kiosks.

\subsubsection{Purpose of Using Delivery Channels}

It is significant to note that approximately $71 \%$ respondents are using delivery channels for fund transfer and account information. $64 \%$ respondents are using delivery channels for bill payments. Only $35 \%$ respondents are using delivery channels for buying household stuff and $26 \%$ respondents are using delivery channels for online trading. Further, $23 \%$ respondents are using channels for online deposits. It is also significant to note that $38 \%$ respondents are using delivery channels for online tax payments, $25 \%$ respondents are using for ECS.

\subsubsection{Customers Usage frequency for Technology-enabled Delivery Channels}

It is remarkable to note that $45 \%$ respondents are using ATMs up to 5 times a month, may be for convenience of withdrawal anytime anywhere. But, this may be reduced to up to 4 times due to rider imposed by RBI for charging fee for more than 4 times. The research also shows that only $15 \%$ respondents found to be frequent user of online trading. It was alarming to note that $33 \%$ respondents have never visited their Bank's website and $73 \%$ respondents still visit Bank's branches at least once a month and $57 \%$ up to the extent of five times in a month.

\subsection{Inference Statistics}

ANOVA has been used for testing the hypothesis with respect to two most influencing demographic variables such as age groups and annual income.

(1) Objective: To Identify the Usage Pattern of Technology-enabled Delivery Channels with respect to Age Groups

\section{Assumption:}

$\mathrm{H}_{0}: \mu_{(18-25)}=\mu_{(26-35)}=\mu_{(36-45)}=\mu_{(46-59)}=\mu_{(>59)}$
$\mathrm{H}_{1}: \mu_{(18-25)} \neq \mu_{(26-35)} \neq \mu_{(36-45)} \neq \mu_{(46-59)} \neq \mu_{(>59)}$ 
Table 1. ANOVA

\begin{tabular}{|c|c|c|c|c|c|c|}
\hline \multirow{2}{*}{$\frac{\text { Parameters }}{\text { ATM usage }}$} & \multirow[b]{2}{*}{ Between Groups } & \multicolumn{2}{|c|}{ Sum of Squares df } & \multicolumn{2}{|c|}{ Mean Square F } & \multirow{2}{*}{$\begin{array}{r}\text { Sig. } \\
.009\end{array}$} \\
\hline & & 13.365 & 4 & 3.341 & 3.426 & \\
\hline & Within Groups & 361.869 & 371 & .975 & & \\
\hline & Total & 375.234 & 375 & & & \\
\hline \multirow[t]{3}{*}{ Tele-banking usage } & Between Groups & .802 & 4 & .200 & 0.469 & .759 \\
\hline & Within Groups & 158.557 & 371 & .427 & & \\
\hline & Total & 159.359 & 375 & & & \\
\hline \multirow[t]{3}{*}{ Internet banking usage } & Between Groups & 96.208 & 4 & 24.052 & 14.139 & .000 \\
\hline & Within Groups & 631.129 & 371 & 1.701 & & \\
\hline & Total & 727.338 & 375 & & & \\
\hline \multirow[t]{3}{*}{ Mobile banking usage } & Between Groups & 11.308 & 4 & 2.827 & 2.719 & .030 \\
\hline & Within Groups & 385.732 & 371 & 1.040 & & \\
\hline & Total & 397.040 & 375 & & & \\
\hline \multirow[t]{3}{*}{ Branch lobby kiosks } & Between Groups & .522 & 4 & .130 & 0.278 & .892 \\
\hline & Within Groups & 173.893 & 371 & .469 & & \\
\hline & Total & 174.415 & 375 & & & \\
\hline
\end{tabular}

Analysis of variance testing in Table 1 reveals that the F value (3.426) for ATMs usage, F value (14.319) for Internet banking and $\mathrm{F}$ value (2.719) for mobile banking usage are more than the $\mathrm{F}$ critical value (2.37). It represents that the mean value for the same population or at least one is significantly different. The variability between sample mean is larger than the variability within each sample. This shows that usage pattern of ATMs, Internet banking and Mobile Banking among different age groups are significantly different. Thus, $\mathrm{H}_{0}$ is rejected.

The F-value (0.469) for Tele-banking usage and F-value (0.278) for branch lobby kiosks are lesser than the F critical value (2.37), hence the mean difference in the usage pattern for Tele-banking and branch lobby kiosks among various age groups is not significant and the $\mathrm{H}_{0}$ is accepted.

(2) Objective: To Identify the Usage Pattern of Technology-enabled Delivery Channels with respect to Annual Income

\section{Assumption:}

$\mathrm{H}_{0}: \mu_{(<2 \text { lakhs })}=\mu_{(2 \text { lakhs to } 5 \text { lakhs })}=\mu_{(>5 \text { lakhs to } 10 \text { lakhs })}=\mu_{(>10 \text { lakhs })}$

$\mathrm{H}_{1}: \mu_{(<2 \text { lakhs })} \neq \mu_{\text {(2 lakhs to } 5 \text { lakhs })} \neq \mu_{(>5 \text { lakhs to } 10 \text { lakhs })} \neq \mu_{(>10 \text { lakhs })}$ 
Table 2. ANOVA

\begin{tabular}{|c|c|c|c|c|c|c|}
\hline Parameters & & Sum of Squares & $\mathrm{df}$ & Mean Square & $\mathrm{F}$ & Sig. \\
\hline \multirow[t]{3}{*}{ ATM usage } & Between Groups & 4.248 & 4 & 1.062 & 1.062 & .375 \\
\hline & Within Groups & 370.986 & 371 & 1.000 & & \\
\hline & Total & 375.234 & 375 & & & \\
\hline \multirow[t]{3}{*}{ Tele-banking usage } & Between Groups & 1.413 & 4 & .353 & 0.830 & .507 \\
\hline & Within Groups & 157.946 & 371 & .426 & & \\
\hline & Total & 159.359 & 375 & & & \\
\hline \multirow[t]{3}{*}{ Internet banking usage } & Between Groups & 29.645 & 4 & 7.411 & 3.941 & .004 \\
\hline & Within Groups & 697.693 & 371 & 1.881 & & \\
\hline & Total & 727.338 & 375 & & & \\
\hline \multirow[t]{3}{*}{ Mobile banking usage } & Between Groups & 4.298 & 4 & 1.074 & 1.015 & .399 \\
\hline & Within Groups & 392.742 & 371 & 1.059 & & \\
\hline & Total & 397.040 & 375 & & & \\
\hline \multirow[t]{3}{*}{ Branch lobby kiosks } & Between Groups & 1.509 & 4 & .377 & 0.809 & .520 \\
\hline & Within Groups & 172.906 & 371 & .466 & & \\
\hline & Total & 174.415 & 375 & & & \\
\hline
\end{tabular}

Analysis of variance testing in Table 2 reveals that the F value (3.941) for Internet banking usage is more than the F critical value (2.37). It represents that the mean value for the same population or at least one is significantly different. The variability between sample mean is larger than the variability within each sample. This shows that usage pattern of Internet banking among different age groups is significantly different. Thus, $\mathrm{H}_{0}$ is rejected.

The F-value (1.062) for ATM usage, F-value (0.830) for Tele-banking usage, F-value (1.015) for mobile banking usage and F-value (0.809) for branch lobby kiosks are lesser than the F critical value (2.37). Hence, the mean difference in the usage pattern for ATMs, Tele-banking, mobile banking and branch lobby kiosks amongst various age groups is not significant and the $\mathrm{H}_{0}$ is accepted.

\section{Results and Discussions}

The overall financial eco-system significantly points towards the rapid penetration of technology in the banking services, which augur well for the future technological advancements / disruptions lying in store. There exists an opportunity for the banks to adopt such innovation and render superior services to their esteemed customers. The impact of these digital innovations on banks goes beyond their technology, security and infrastructure capabilities: it is opening up new business models and propositions. Redefining the customer experience, and enabling new potential from employees and business networks. Followings are the findings of our study:

It has been researched that the PSBs are having good technology and innovative delivery channels infrastructure as well as interfaces with the internal and external applications. The analysis reveals that customers are having good perception about technology-enabled innovative delivery channels. The results indicate that in Mumbai city, younger age groups are forming the major users of technology-enabled delivery channels.

Furthermore, $71 \%$ of the respondents are using delivery channels for fund transfer and account information. The results also show that an ATM service is used more as compare to internet banking and mobile banking among age groups 36-45 and annual income above five lakhs to ten lakhs. This indicates there is huge scope of exploring the usage of delivery channels for other purposes such as buying household stuffs, online shopping and so on.

The statistical analysis shows that the usage pattern for technology-enabled delivery channels varies on age groups and annual income of customers. It indicates that usage pattern of Internet banking is dependent of age groups and annual income of respondents. While, Tele-banking and branch lobby kiosks are independent of age groups and annual income. It indicates that customers of age groups 26-35 and annual income of two lakhs to five lakhs find Internet banking more convenient for electronic fund transfer and bill payments. Hence, banks can come up with tie-ups with supplementary \& complementary services to enhance the usage of delivery channels through these channels to optimize the cost of banking operations. 
Disruptive digital financial services are powerful, pervasive and have multiple indirect impacts on banking and financial system. They reduce barriers to entry, blur category boundaries, and open doors for a new generation of entrepreneurs and smart thinkers. At the same time, incumbent market leaders face substantial pressures, which they need to manage if they are to thrive, let alone survive.

The Banks have their technology-enabled products and services at par with global Banks, but the usage are not at par. Specific banks may study their customer's usage pattern, awareness level and service quality, to enhance the marketing of their products and services through innovative delivery channels. PSBs may educate their employees to use more and more innovative delivery channels. This will not only cut the usage cost, but also train the employees for innovative delivery channels and in turn, they will educate the customers for the same.

\section{Implications of Research}

The e-banking study mentioned earlier underpins that for a customer, experience is all about what transpires at the customer satisfaction. Consequently, banks must not only provide high quality experience on every channel, but in this age of multi-channel banking / eBanking, also ensure an integrated and seamless service that enables customers to switch effortlessly between various delivery channels. Although many banks have launched customer engagement programs, very few have been able to show tangible results. Re-launching a brand or revamping a channel or branch network is ineffective without a well-designed and perfectly executed plan for enhancing customer experience.

Public Sector Banks can use this significant analysis for studying the effectiveness of their delivery channels. In this competitive era, return on investment may not be the prime objective of adopting innovative delivery channels for delivery of banking products and services. The modification and improvements in the innovative delivery channels for marketing banking products and services can be helpful for banks in retaining and acquiring the customers. As technology adoption and customization based on market and customer demand is must have strategy for corporate to lead sustainability.

\section{Limitation of Research}

The scope of the study was selected PSBs' customers residing in Mumbai city (India). Hence the findings of this study could be closely associated with PSBs only. The findings of this study may be mapped to the service quality model for delivery of financial products and services in technological environment.

\section{References}

Alam, S. S., Musa, R., \& Hassan, F. (2009). Corporate Customers' Adoption of Internet Banking: Case of Klang Valley Business Firm in Malaysia. International Journal of Business and Management, 4(4), 14-21. http://dx.doi.org/10.5539/ijbm.v4n4p13

Cheng, S., Lee, S. J., \& Lee, K. R. (2014). User Resistance of Mobile Banking in China: Focus on Perceived Risk. International Journal of Security and Its Applications, 8(2), 167-172. http://dx.doi.org/10.14257/ijsia.2014.8.2.17

Cruz, P., Laukkanen, T., \& Munoz, P. (2009). Exploring the factors behind the resistance to mobile banking in Portugal. International Journal of E-services and Mobile Applications, 1(4), 16-35. http://dx.doi.org/10.4018/jesma.2009070802

Davis, F. D. (1989). Perceived usefulness, perceived ease of use, and user acceptance of information technology. MIS Quarterly, 13(3), 319-340. http://dx.doi.org/10.2307/249008

Dharmarajan, S., \& Srinivasan, T. (2007). Information Technology in Banking Services-Trends, Issues and Challenges. Paper Presented at The National Conference on Recent Trends in Financial Services held By the Department of Commerce, Directorate of Distance Education, Annamalai University held on 12th October, 2007.

Fain, D., \& Roberts, M. L. (1997). Technology vs consumer behavior: the battle for the financial services $\begin{array}{lllll}\text { customer. Journal of } & \text { Direct }\end{array}$ http://dx.doi.org/10.1002/(SICI)1522-7138(199724)11:1<44:AID-DIR5>3.0.CO;2-Z

Gerrard, P., Cunningham, J. B., \& Devlin, J. F. (2006). Why consumers are not using internet banking. Journal of Services Marketing, 20(3), 160-168. http://dx.doi.org/10.1108/08876040610665616

Grönroos, C. (1982). An Applied Service Marketing Theory. European Journal of Marketing, 16(7), 30-41. http://dx.doi.org/10.1108/EUM0000000004859 
Grönroos, C., Heinonen, F., Isoniemi, K., \& Lindholm, M. (2000). The Net Offer model: A case example from the virtual marketspace. Management Decision, 38(4), 243-252. http://dx.doi.org/10.1108/00251740010326252

Howcroft, J. B. (1993). Branch Networks and Alternative Distribution Channels: Threats and Opportunities. International Journal of Bank Marketing, 11(6), 26-31. http://dx.doi.org/10.1108/02652329310045738

Joseph, H. (1996). Internet marketing practices. Information Management \& Computer Security, 4(5), 7-14. http://dx.doi.org/10.1108/09685229610153120

Kang, G., \& James, J. (2004). Service quality dimensions: An examination of Grönroos's service quality model. Managing Service Quality: An International Journal, 14(4), 266-277. http://dx.doi.org/10.1108/09604520410546806

Khanna, V. T., \& Gupta, N. (2015). Customer's Perception about Banks Technology for Innovative Delivery Channels of Public Sector Banks (PSBs) of India. International Journal of Business and Management, 10(2), 214-225. http://dx.doi.org/10.5539/ijbm.v10n2p214

Kumbhar, V. (2009). Alternative Banking: An Modern Practice in India. Professional Banker, 9(9), 54-58. Retrieved from http://ssrn.com/abstract=1473898, PBSC40912

Kundu, S., \& Datta, S. K. (2012). A comparative evaluation of customer perception and satisfaction of M-banking and I-banking. Journal of Transnational Management, 17, 118-136. http://dx.doi.org/10.1080/15475778.2012.676977

Lang, B., \& Colgate, M. (2003). Relationship quality, online banking and the information technology gap. International Journal of Bank Marketing, 21(1), 29-37. http://dx.doi.org/10.1108/02652320310457785

Laukkanen, P., Sinkkonen, S., \& Laukkanen, T. (2008). Consumer resistance to internet banking: Postponers, opponents and rejectors. International Journal of Bank Marketing, 26(6), 440-455. http://dx.doi.org/10.1108/02652320810902451

Laukkanen, T., Sinkkonen, S., \& Laukkanen, P. (2009). Communication strategies to overcome functional and psychological resistance to internet banking. International Journal of Information Management, 29(2), 111-118. http://dx.doi.org/10.1016/j.ijinfomgt.2008.05.008

Laukkanen, T., Sinkkonen, S., Kivijärvi, M., \& Laukkanen, P. (2007). Innovation resistance among mature consumers. Journal of Consumer Marketing, 24(7), 419-427. http://dx.doi.org/10.1108/07363760710834834

Mariappan, V. (2005). Changing the way of Banking in India: Technology as Drivers-What is the Triger. Vinimaya, 26(2).

Martin, C. L. (2012). A quarter of a century: Reflections of the first 25 years of the Journal of Services Marketing. Journal of Services Marketing, 26(1), 3-8. http://dx.doi.org/10.1108/08876041211199670

Murari, K., \& Tater, B. (2014). Employee's attitude towards adoption of IT-based banking services: A case of Indian private sector banks. Competitiveness Review, 24(2), 107-118. http://dx.doi.org/10.1108/CR-01-2013-0005

Parasuraman, A. (2000). Technology readiness index (TRI): A multiple-item scale to measure readiness to embrace new technologies. Journal of Service Research, 2(4), 307-320. http://dx.doi.org/10.1177/109467050024001

Parasuraman, A., Zeithaml, V. A., \& Berry, L. L. (1985). A conceptual model of service quality and its implications for future research. Journal of Marketing, 49(4), 41-50. http://dx.doi.org/10.2307/1251430

Patrício, L., Fisk, R. P., \& Cunha, J. F. (2003). Improving satisfaction with bank service offerings: Measuring the contribution of each delivery channel. Managing Service Quality: An International Journal, 13(6), 471-482. http://dx.doi.org/10.1108/09604520310506531

Ram, S., \& Sheth, J. N., (1989). Consumer Resistance to Innovations: The Marketing Problem and its solutions. Journal of Consumer Marketing, 6(2), 5-14. http://dx.doi.org/10.1108/EUM0000000002542

Uppal, R. K. (2010). Paradigm Shift in e-Banking: Some Evidence from Indian Banks. IUP Journal of Bank Management, $9(1 \& 2), 42-59$. http://dx.doi.org/10.1504/IJEED.2010.032879

Xue, M., Hitt, L. M., \& Harker, P. T. (2007). Customer Efficiency, Channel Usage, and Firm Performance in Retail Banking. Manufacturing \& Service Operations Management, 9(4), 535-558. http://dx.doi.org/10.1287/msom.1060.0135 
Zineldin, M. (2000). Beyond relationship marketing: Technologicalship marketing. Marketing Intelligence \& Planning, 18(1), 9-23. http://dx.doi.org/10.1108/02634500010308549

\section{Copyrights}

Copyright for this article is retained by the author(s), with first publication rights granted to the journal.

This is an open-access article distributed under the terms and conditions of the Creative Commons Attribution license (http://creativecommons.org/licenses/by/3.0/). 